\title{
Scale Development for M-Commerce Acceptance vis-à-vis Young, Educated, Non-Metropolitan Small Town Consumers in India
}

\author{
Lamay Bin Sabir ${ }^{\mathrm{a} \bowtie}$, Mohd Danish Kirmani ${ }^{\mathrm{b}}$ \\ ${ }^{a}$ Faculty of Management Studies and Research, Aligarh Muslim University, India \\ ${ }^{b}$ Department of Management Studies, Galgotias College of Engineering and Technology, \\ India
}

\begin{abstract}
The primary aim of the present study was to develop a validated measuring scale for $\mathrm{m}$ commerce acceptance among educated young people in non-metropolitan India. Data was generated from students enrolled in higher educational institutions located in Aligarh district in Uttar Pradesh employing a close-ended structured questionnaire. Analysis utilized Exploratory Factor Analysis (EFA) and Confirmatory Factor Analysis (CFA). Based on findings, the study proposes Mobile Commerce (MC) scale for measuring the level of $\mathrm{m}$ commerce acceptance by Indian consumers. MC scale comprise of four factors, namely, utility, perceived ease of use, perceived innovation in information technology and intention to use. Findings also revealed that the educated young Indian consumers of non-metropolitan cities are ambitious and choose innovativeness over cost and risk for using new technology. On a broader note, it can be proposed that educated youth of non-metropolitan India resemble their global counterparts through relying more on positive factors than negative factors such as cost and risk.
\end{abstract}

Keywords: Educated Youth, Indian Consumers, M-commerce, Non-metropolitan Area, Scale Development

Received:

22 October 2019
Accepted revised version:

18 April 2020
Published:

30 June 2020

Suggested citation: Sabir, L. B., \& Kirmani, M. D. (2020). Scale development for Mcommerce acceptance vis-à-vis young, educated, non-metropolitan small town consumers in India. Colombo Business Journal. 11(1), 105-131.

DOI: http://doi.org/10.4038/cbj.v11i1.59

(C)2020 The Authors. This work is licenced under a Creative Commons Attribution 4.0 International Licence which permits unrestricted use, distribution, and reproduction in any medium, provided the original work is properly cited.

lamaybinsabir@gmail.com: (iD) https://orcid.org/0000-0002-7378-0293 


\section{Introduction}

Mobile commerce (M-Commerce), is a subset of electronic commerce (ecommerce) that involves the use of mobile device for online transaction of commodities, services and information (Clarke, 2008; Feng et al., 2007; June, 2014; Varshney \& Vetter, 2002; Wong \& Hsu, 2008; Wu \& Wang, 2005). Due to features such as mobility, reachability, usage patterns and different interaction styles, mcommerce provides an innovative model for investing, banking, shopping, and other services (Eastin, 2002; Mohsin et al., 2003; Tiwari \& Buse, 2007; Wei et al., 2009). There has been a rapid expansion in the use of mobile internet services across the globe (Lu et al., 2003; Lu et al., 2005; Yang et al., 2004). This is evident in the increased number (from 95 million in 2003 to 5.2 billion in 2019) of global mobile subscribers (GSM Association (GSMA), 2020). According to the estimations of a report by GSMA (2020), the number of global mobile subscribers will reach 5.8 billion by 2025 .

GSMA (2020) also posited that the future growth in the mobile internet services will be driven by developing countries such as India. The sales through $\mathrm{m}$-commerce in India was around 6 billion US dollars in the financial year 2015-2016 (Statista.com, 2016). In 2017, it was observed in a study by the Associated Chambers of Commerce and Industry (ASSOCHAM) in India that, mobile phones were the preferred device to be used by most Indian consumers for online shopping (Press Trust of India, 2017). The number of mobile subscribers is expected to further increase in future due to offering of a wide range of activities such as health care, agricultural extension services, genomics, advanced geographic information system, etc. (McKinsey Global Institute, 2014). According to McKinsey Global Institute (2014), there will be around 900 million mobile internet users in India by 2025 . The annual sales are, in fact, expected to reach 38 billion US dollars by 2020 (Statista.com, 2016).

On one hand, m-commerce offers benefits such as efficiency, convenience, wider selection options and rich information (June, 2014). The researchers have highlighted effectiveness of m-commerce in shopping, banking services, easy payment options, etc. (Chong et al., 2012; Eastin, 2002; June, 2014; Tiwari \& Buse, 2007; Wei et al., 2009). On the other hand, there are some concerns related to m-commerce such as cost, privacy issues and risk (Plouffe et al., 2001). These concerns can have a bearing on the consumer intention to embrace m-commerce (Hung et al., 2012). Due to this, it is imperative for marketers to have a clear understanding of the factors that could stimulate consumers for the acceptance of mobile commerce. In this regard, previous researchers have identified several factors such as perceived ease of use, perceived 
cost, perceived usefulness, compatibility, perceived risk, intention to use etc. for predicting consumer acceptance of mobile commerce (Choi, 2018; Chou et al., 2010; June, 2014; Kim et al., 2009; Liébana-Cabanillas et al., 2017; Wu \& Wang, 2005).

In the Indian context, it should be noted that a large population is living in the non-metropolitan part of the country (Ministry of Home Affairs, 2011; Lu et al., 2016). Non-metropolitan population includes those who reside in small towns and villages where the population is less than four million (Ministry of Home Affairs, 2011). The earlier studies have suggested that the Indian consumers residing in small towns and villages are not confortable with the new technologies. They are observed to be reluctant in embracing new technologies as they not only consider these technologies risky but are also skeptical about their abilities to use new technologies (Chauhan, 2015; Thakur \& Srivastava, 2013; Trivedi \& Kumar, 2014; Yadav et al., 2016). Further, cost is also an issue for the non-metropolitan consumers since a majority of these consumers lives on a medicore income and spending extra for using a new technology is a major issue for them (Chauhan, 2015; Thakur \& Srivastava, 2013; Trivedi \& Kumar, 2014; Yadav et al., 2016). This suggests that the factors such as perceived risk, perceived ease of use, perceived cost, etc. could be very crucial for influencing them to embrace a new technology such as mobile commerce.

Past studies based on feedbacks from consumers residing in metropolitan cities in India have identified the factors crucial for acceptance of a new technology by consumers. For example, Thakur and Srivastava (2013) identified that factors such as perceived usefulness and perceived ease of use are important determinants of intentions of Indian consumers to embrace m-commerce. Similarly, Yadav et al. (2016) examine the variables such as perceived cost, perceived trust, social influence and variety of services in the context of m-commerce acceptance by Indian consumers. Other researchers such as Trivedi and Kumar (2014) and Chauhan (2015) have also attempted to examine different dimensions associated with the $\mathrm{m}$ commerce acceptance by Indian consumers. In the global context too, the observations are largely based on the feedback generated from consumers residing in the national capitals or metropolitan cities (Chong et al., 2012; Chou et al., 2010; Eastin, 2002; June, 2014; Kim et al., 2009; Liébana-Cabanillas et al., 2017; Tiwari \& Buse, 2007; Wei et al., 2009; Wu \& Wang, 2005).

Recent studies have suggested that the small towns are offering a great potential for the promotion of m-commerce in India (Bali, 2016; Kalaari Capital Report, 2017). In this regard, the primary challenge for marketers is the fundamental understanding of non-metropolitan Indian consumers who are considered to be different from 
metropolitan consumers (Maheshkar et al., 2018). Presently, a well defined scale determining m-commerce acceptance by the non-metropolitan Indian consumers is missing. Thus, there was a pressing need to examine the preferences of Indian consumers residing in non-metropolitan part of the country. Hence, the primary aim of the present study was to develop a validated measuring scale for m-commerce acceptance among educated young people in non-metropolitan India.

\section{Literature review}

There are several studies that examined the consumer acceptance of new technologies. Most widely refered research is the study by Davis (1989) in which he proposed the Technological Acceptance Model (TAM). TAM was developed based on the theoretical foundations of Theory of Reasoned Action (TRA) developed by Fishbein and Ajzen (1975). While TRA explained general human behaviour, TAM was more focused on explaining the determinants of technological acceptance. According to TAM, perceived ease of use and perceived usefulness are the antecedents that helps in developing attitude towards technology, behavioural intention and hence, leads to actual usage (Wallace \& Sheetz, 2014; Wijesundara \& Xixiang, 2018). The observations by Davis (1989) found support in a significant number of later studies. For example, the researchers such as Lederer et al., (2000) and Jeyaraj et al. (2006) opined that perceived usefulness is crucial to explain consumer acceptance of a new technology. In the context of m-commerce too, researchers have reiterated that the perceived usefulness is critical to understand the consumer acceptance (Chou et al., 2010; Hung et al., 2007; Kim et al., 2009; LiébanaCabanillas et al., 2017; Lin \& Shih, 2008; Lu et al., 2005; Taylor \& Strutton, 2010). Similarly, researchers also supported the crucial role of perceived ease of use in explaining technological acceptance by consumers (Choi, 2018; Choi et al., 2011; Chong et al., 2012; Ha et al., 2007; June, 2014; Kim et al., 2009; Lederer et al., 2000; Liébana-Cabanillas et al., 2017; Liu \& Forsythe, 2011; Nysveen et al., 2005; Sadia, 2011; Taylor \& Strutton 2010; Zhou, 2011).

Researchers have also proposed the extension of TAM by integrating new variables in order to incorporate the latest trends (Akter et al., 2011; Kim, 2012; Lucas \& Spitler, 2000; Ng \& Kwahk, 2010; Szajna, 1996; Venkatesh \& Davis, 2000; Venkatesh \& Morris, 2000; Wei et al., 2009). In this regard, TAM was revised into TAM2 (Venkatesh \& Davis, 2000) and TAM3 (Venkatesh \& Bala, 2008). TAM2 included social influence and cognitive instrumental processes and TAM3 examined the antecedents of perceived ease of use (Rondan-Cataluna et al., 2015; Wijesundara \& Xixiang, 2018). However, in a recent study, June (2014) observed a weak link 
between social influence and consumer decision to accept a new technology. It should also be noted that TAM2 omitted 'attitude' as it was observed to be a weak predictor of intention and actual usage (Venkatesh \& Davis, 2000; Wu \& Wang, 2005). TAM was also modified by a significant number of other researchers (Choi, 2018; Chong et al., 2010; Chou et al., 2010; Hsu \& Lu, 2004; Jeyaraj et al., 2006; June, 2014; Lederer et al., 2000; Lu et al., 2005; Taylor \& Strutton, 2010; Venkatesh \& Davis, 2000; Wei et al., 2009; Wu \& Wang, 2005).

In the context of mobile commerce, Wu and Wang (2005) developed the extended TAM that integrated innovation diffusion theory, perceived risk and cost in the original TAM. With reference to cost, Grandon and Pearson (2004) identified three components - cost of equipment, transaction cost and access cost for using a technology. In addition, consumers also incur additional cost due to slow connections, out-of-date content, poor quality, errors and missing links (Wu \& Wang, 2005). With regard to perceived risk, researchers opined that safety concern of consumers is critical for their decision to accept a new technology (Gefen \& Straub, 2003; Lin \& Chen, 2012; Moorman et al., 1992; Suh \& Han, 2002; Sultan \& Mooraj, 2001;Taylor, 1974; Warrington et al., 2000; Zhou, 2011; Zhao et al., 2012). More specifically, the usage of a technology involves privacy and security risks that may lead to fraud and loss for consumers (Ba \& Pavlou; 2002; Bagozzi \& Yi, 1998; Cho, 2004; Forsythe \& Shi, 2003).

Researchers have also examined the role of consumer innovativeness in explaining the technological acceptance by consumers (Aldas-Manzano et al., 2009; Han et al., 2006; Hung et al., 2007; Kwon et al., 2007; Lu et al., 2005; Sun, 2012; Wu, et al. , 2011; Yi et al.., 2006; Zhao et al., 2012). Agarwal and Prasad (1998) posited that the adoption of a new technology is dependent upon the degree of innovativeness among the consumers. June (2014) observed the critical role of personal innovativeness in explaining consumer intention to accept mobile commerce.

Some important constructs discussed in the previous research are available in Table 1. The factors examined by the previous researchers can be classified into two groups. First, there are constructs that can motivate consumers to accept a new technology. These constructs such as perceived ease of use, perceived usefulness, personal innovativeness and intention can be termed as positive factors. Other factors such as perceived risk and cost tend to deter the consumers from accepting a new technology, and hence, they can be termed as negative factors. A significant number 
of earlier studies focus on examining the positive factors only (Choi, 2018; Chong et al., 2010; Chou et al., 2010; Davis, 1989; Hsu \& Lu, 2004; Jeyaraj et al., 2006; June, 2014; Lederer et al., 2000; Lu et al., 2005; Taylor \& Strutton, 2010; Venkatesh \& Davis, 2000; Wei et al., 2009; Wu \& Wang, 2005). Only Wu and Wang (2005) examined the combination of positive and negative factors. However, Wu and Wang (2005) have examined only the compatibility aspect of personal innovativeness. In the Indian context, Trivedi and Kumar (2014) examined only positive factors to understand the technological acceptance by consumers. Thakur and Srivastava (2013) considered the perceived risk but did not examine cost in their technological acceptance model. The cost of using a technology was examined by Yadav et al. (2016) but they did not examine the risk factor in their study. In sum, there is an absence of a study examining all positive and negative factors together in determining consumer acceptance of a new technology.

Table 1: Important Constructs Discussed in Previous Research

\begin{tabular}{|c|c|c|}
\hline Construct & Definition & Studies \\
\hline $\begin{array}{l}\text { Perceived ease } \\
\text { of use }\end{array}$ & $\begin{array}{l}\text { Degree of consumer belief } \\
\text { that using a particular } \\
\text { product is free from efforts }\end{array}$ & $\begin{array}{l}\text { Davis, 1989; Ledererer al., 2000; } \\
\text { Nysveen et al., 2005; Ha et al., 2007; } \\
\text { Kim et al., 2009; Sadia, 2011; Liu \& } \\
\text { Forsythe, 2011; Zhou, 2011; Chong et } \\
\text { al., 2012; June, 2014; Liébana- } \\
\text { Cabanillas et al., 2017 }\end{array}$ \\
\hline $\begin{array}{l}\text { Perceived } \\
\text { usefulness }\end{array}$ & $\begin{array}{l}\text { Degree of consumer belief } \\
\text { that using a particular } \\
\text { product would increase his } \\
\text { effectiveness }\end{array}$ & $\begin{array}{l}\text { Davis, 1989; Lederer et al., 2000; } \\
\text { Venkatesh \& Davis, 2000; Hsu \& Lu, } \\
\text { 2004; Lu et al., 2005; Wu \& Wang, } \\
\text { 2005; Jeyaraj et al., 2006; Wei et al., } \\
\text { 2009; Chong et al., 2010; Chou et al., } \\
\text { 2010; Taylor \& Strutton, 2010; June, } \\
\text { 2014; Liébana-Cabanillas et al., 2017; } \\
\text { Choi, } 2018 .\end{array}$ \\
\hline Percieved risk & $\begin{array}{l}\text { Customer's perception of } \\
\text { lack of trust and the potential } \\
\text { adverse effects of purchasing } \\
\text { a good or service }\end{array}$ & $\begin{array}{l}\text { Taylor, 1974; Moorman et al., 1992; } \\
\text { Warrington et al., 2000; Sultan \& } \\
\text { Mooraj, 2001; Gefen \& Straub, 2003; } \\
\text { Bagozzi, 1998; Ba \& Pavlou, 2002; } \\
\text { Forsythe \& Shi, 2003; Suh \& Han, } \\
\text { 2002; Zhou, 2011; Lin \& Chen, 2012; } \\
\text { Zhao et al., 2012. }\end{array}$ \\
\hline Perceived cost & $\begin{array}{l}\text { The unit cost that a } \\
\text { consumer believes he incurs } \\
\text { while using a technology. }\end{array}$ & $\begin{array}{l}\text { Dai \&Palvia, 2008; Wei et al., 2009; } \\
\text { Wu \& Wang, 2005; Lu et al., } 2016 .\end{array}$ \\
\hline
\end{tabular}




\begin{tabular}{|c|c|c|}
\hline Construct & Definition & Studies \\
\hline $\begin{array}{l}\text { Innovativeness } \\
\text { in Information } \\
\text { Technology }\end{array}$ & $\begin{array}{l}\text { An indicator of the degree of } \\
\text { risk tolerance among } \\
\text { consumers and their } \\
\text { confidence to use a new } \\
\text { technology. }\end{array}$ & $\begin{array}{l}\text { Agarwal \& Prasad, 1998; Lu et al., } \\
\text { 2005; Kwon et al., 2007, Han et al., } \\
\text { 2006; Yi et al., 2006; Hung et al., 2007; } \\
\text { Aldas-Manzano et al., 2009; Wu et al., } \\
\text { 2011; Sun, 2012; Zhao et al., 2012; } \\
\text { June, 2014. }\end{array}$ \\
\hline Intention to use & $\begin{array}{l}\text { The consumer likelihood to } \\
\text { accept a technology }\end{array}$ & Wu \& Wang, 2005 \\
\hline
\end{tabular}

In this regard, it is imperative to understand whether the cost and risk are important considerations for non-metropolitan contexts such as what is found in India (Dai \& Palvia, 2008; Wei et al., 2009). According to Kumar (2007), Indian consumers in small towns and villages are cost consicious and prudent while making acceptance decisions. This is also supported by Maheshkar et al. (2018) in their assertion that unlike urban consumers, the non-metropolitan Indian consumers are driven by their needs and income. Chauhan (2015), in a study based on poor Indian citizens, opined that the chances of technological acceptance by consumers increase when they feel safe about using the technology.

It is in light of these drawbacks of currently available measurement instruments that this paper seeks to develop a more suitable scale for m-commerce acceptance among educated young people in non-metropolitan India.

\section{Research methodology}

The present study followed the procedures suggested by earlier studies such as Churchill (1979), Hinkin (1995), Tanwar and Prasad (2017) and Ahmad and Khan (2017) for the purpose of scale development.

\section{Item Generation}

The items to measure perceived ease of use, perceived usefulness and intention were used in various studies on technological acceptance model (Davis, 1989; Hsu \& Lu, 2004; Lederer et al., 2000; Lu et al., 2005; Venkatesh \& Davis, 2000). These items were refined by Wu and Wang (2005), Chong et al. (2012) and June (2014) in the context of mobile commerce. Further, Wu and Wang (2005) also used the perceived risk and cost to measure consumer acceptance of mobile commerce. June (2014) comprehensively measured personal innovativeness of consumers in connection with the acceptance of mobile commerce. Hence, the items for the present 
study were adapted from the studies by Wu and Wang (2005), Chong et al. (2012) and June (2014). Table 2 indicates the sources of individual items. These items were measured based on a 5-point likert scale.

For the purpose of pre-testing, 10 academicians from a reputed university funded by the central government of India and located in the northern region of the country were consulted (as recommended by Hinkin, 1995). They were requested to check the questionnaire items for relevance, wording, ease of understanding and other inconsistencies. These academicians were of the view that the language of some items can be more simplified to make them more relevant in the Indian context. Based on their suggestions, those items were rephrased. The questionnaire was again sent to the academicians and after their approval, it proceeded for pilot testing. The questionnaire items that were rephrased are highlighted in bold in Table 2 .

\section{Pilot Testing and Exploratory Factor Analysis}

A pilot survey was performed to check the unidimensionality of the scales (Sekaran, 2003; Malhotra, 2008). Hence, it was decided to generate data from a small sample of 100 as also recommended by a significant number of earlier researchers (Cooper \& Schindler, 1998; Hair et al., 2010). Exploratory Factor Analysis (EFA) was performed using SPSS 20. The factor extraction and rotation was performed using principal component analysis and varimax rotation with Kaiser Normalisation. The items with low factor loadings $(<0.4)$ were eliminated and a refined scale of 6 variables and 22 items was obtained (Kline 1994; Hinkin, 1995; Malhotra \& Dash, 2011; Metin et al. 2012). The significant value $(<0.05)$ of Bartlett's Test of Sphericity (BTS) and acceptable value $(0.749>0.6)$ of Kaiser-Meyer-Olkin (KMO) established the sample adequacy for performing EFA (as recommended by Khan \& Adil, 2013; Malhotra \& Dash, 2011). The 6 factors extracted explain $62.7 \%$ of the total variance. The Cronbach's alpha values for all six variables were also found to be in the range of 0.768 to 0.860 which is acceptable since they are higher than 0.7 (Hair et al. 1998; Kerlinger \& Lee 2000; Khan \& Adil 2013). This Indian version of the scale comprising six variables can be termed as MC scale (mobile commerce acceptance scale).

It should be noted that in Table 2, five factors (perceived risk, perceived cost, perceived ease of use, intention to use and innovativeness in information technology) has already been used in the earlier studies. However, the factor 'utility' is new. This factor has combination of items measuring the compatibility of user with technology (S9 and S10) and their perceived usefulness (S11-S15). 
Table 2: Items and EFA Results

\begin{tabular}{|c|c|c|c|}
\hline $\begin{array}{l}\text { Item } \\
\text { Code }\end{array}$ & Item & $\begin{array}{c}\text { EFA } \\
\text { Loading }\end{array}$ & Factor \\
\hline \multicolumn{4}{|c|}{ Items Retained after EFA } \\
\hline $\mathrm{S} 1 *$ & $\begin{array}{l}\text { I think using Mobile Commerce in monetary } \\
\text { transactions has potential risk. }\end{array}$ & 0.704 & $\begin{array}{l}\text { Perceived Risk } \\
\text { Cronbach's }\end{array}$ \\
\hline $\mathrm{S} 2 *$ & $\begin{array}{l}\text { I think using Mobile Commerce in product } \\
\text { purchases has potential risk. }\end{array}$ & 0.808 & Alpha $=0.848$ \\
\hline $\mathrm{S} 3 *$ & $\begin{array}{l}\text { I think using Mobile Commerce in merchandise } \\
\text { services has potential risk. }\end{array}$ & 0.672 & \\
\hline $\mathrm{S} 5 *$ & $\begin{array}{l}\text { I think the equipment cost is expensive of using } \\
\text { Mobile Commerce. }\end{array}$ & 0.735 & $\begin{array}{l}\text { Perceived Cost } \\
\text { Cronbach's }\end{array}$ \\
\hline S6* & $\begin{array}{l}\text { I think the access cost is expensive of using } \\
\text { Mobile Commerce. }\end{array}$ & 0.850 & Alpha $=0.824$ \\
\hline $\mathrm{S} 7 *$ & $\begin{array}{l}\text { I think the transaction fee is expensive of using } \\
\text { Mobile Commerce. }\end{array}$ & 0.749 & \\
\hline S9* & Using Mobile Commerce fits my lifestyle & 0.732 & Utility \\
\hline $\mathrm{S} 10^{*}$ & $\begin{array}{l}\text { Using Mobile Commerce fits well with the way I } \\
\text { like to engage in online transactions }\end{array}$ & 0.740 & $\begin{array}{l}\text { Cronbach's } \\
\text { Alpha }=0.860\end{array}$ \\
\hline $\mathrm{S} 11^{*}$ & $\begin{array}{l}\text { Using Mobile Commerce would improve my } \\
\text { performance in online transactions. }\end{array}$ & 0.753 & \\
\hline S13* & $\begin{array}{l}\text { Using Mobile Commerce would enhance my } \\
\text { effectiveness in online transactions }\end{array}$ & 0.646 & \\
\hline S14* & $\begin{array}{l}\text { Using Mobile Commerce would make it easier } \\
\text { for me to engage in online transactions }\end{array}$ & 0.581 & \\
\hline $\mathrm{S} 15^{*}$ & $\begin{array}{l}\text { I think using Mobile Commerce is very useful for } \\
\text { me to engage in online transactions }\end{array}$ & 0.708 & \\
\hline $\mathrm{S} 18^{*}$ & $\begin{array}{l}\text { I think becoming skillful at using Mobile } \\
\text { Commerce is easy }\end{array}$ & 0.775 & $\begin{array}{l}\text { Perceived Ease } \\
\text { of Use }\end{array}$ \\
\hline S19* & I think using Mobile Commerce is easy & 0.761 & Cronbach's \\
\hline S20* & $\begin{array}{l}\text { Assuming I had access to Mobile Commerce, I } \\
\text { intend to use it }\end{array}$ & 0.585 & Alpha $=0.792$ \\
\hline S22\# & $\begin{array}{l}\text { I intend to continue using Mobile Commerce in } \\
\text { the future. }\end{array}$ & 0.648 & $\begin{array}{l}\text { Intention to } \\
\text { Use }\end{array}$ \\
\hline S23\# & $\begin{array}{l}\text { As a user, I would keep on using Mobile } \\
\text { Commerce in the future. }\end{array}$ & 0.721 & $\begin{array}{c}\text { Cronbach's } \\
\text { Alpha }=0.768\end{array}$ \\
\hline S25 & $\begin{array}{l}\text { Have free access to Mobile Commerce } \\
\text { applications for a month might convince me to } \\
\text { use it }\end{array}$ & 0.796 & \\
\hline
\end{tabular}




\begin{tabular}{|c|c|c|c|}
\hline $\begin{array}{l}\text { Item } \\
\text { Code }\end{array}$ & Item & $\begin{array}{c}\text { EFA } \\
\text { Loading }\end{array}$ & Factor \\
\hline S27\# & I like to experiment with new technologies. & 0.818 & Innovativeness \\
\hline S29\# & $\begin{array}{l}\text { In general, I would not hesitate to try out new } \\
\text { information technologies. }\end{array}$ & 0.612 & $\begin{array}{c}\text { in Information } \\
\text { Technology }\end{array}$ \\
\hline S30\# & $\begin{array}{l}\text { I would look for ways to experiment with new } \\
\text { technologies. }\end{array}$ & 0.779 & $\begin{array}{c}(\mathbf{I I T}) \\
\text { Cronbach's } \\
\text { Alpha= } 0.848\end{array}$ \\
\hline \multicolumn{4}{|c|}{ Items Not Retained after EFA } \\
\hline $\mathrm{S} 4 *$ & $\begin{array}{l}\text { I think using Mobile Commerce puts my privacy } \\
\text { at risk. }\end{array}$ & $<0.40$ & \\
\hline S8* & $\begin{array}{l}\text { Using Mobile Commerce is compatible with } \\
\text { most aspects of my online transactions }\end{array}$ & $<0.40$ & \\
\hline $\mathrm{S} 12 *$ & $\begin{array}{l}\text { Using Mobile Commerce would increase my } \\
\text { productivity in online transactions }\end{array}$ & $<0.40$ & \\
\hline S16* & I think learning to use Mobile Commerce is easy & $<0.40$ & \\
\hline $\mathrm{S} 17 *$ & $\begin{array}{l}\text { I think finding what I want via Mobile } \\
\text { Commerce is easy }\end{array}$ & $<0.40$ & \\
\hline $\mathbf{S} 21^{@}$ & $\begin{array}{l}\text { Given that I had access to Mobile Commerce, } \\
\text { I predict that I would use it }\end{array}$ & $<0.40$ & \\
\hline $\mathrm{S} 24^{@}$ & $\begin{array}{l}\text { I would like to know more about Mobile } \\
\text { Commerce before using it }\end{array}$ & $<0.40$ & \\
\hline S26 ${ }^{@}$ & $\begin{array}{l}\text { Trial access to 4G might convince me to } \\
\text { subscribe to 4G and use Mobile Commerce. }\end{array}$ & $<0.40$ & \\
\hline
\end{tabular}

Notes: *Items adopted from the study by Wu and Wang (2005)

\#Items adopted from the study by June (2014)

${ }^{\circledR}$ Items adopted from the study by Chong et al. (2012)

\section{Scale Development}

\section{Sample}

Though non-metropolitan part of the country includes both small towns and villages (Minsitry of Home Affairs, 2011), it was decided to generate data from small towns only. This is due to the fact that India is a very large country and differences exist even between the consumers of small towns and villages (Lu et al., 2016). It was decided to generate data from young students enrolled in educational institutes located in the Aligarh district of the largest state of India i.e. Uttar Pradesh. The district of Aligarh is located around 140 kilometers in the southeast of the national capital, New Delhi. Due to proximity to the national capital, easy connectivity to other parts of the country and the presence of Aligarh Muslim University (one of the top 
universities funded by the Federal Government of India), Aligarh is the preferred location of educational institutes and students from other parts of the country.

Previous studies have observed that the proportion of youth (population in the age bracket of 15-29 years) within the total Indian population is around 35\% (Lu et al., 2016; Central Statistics Office, 2017). According to the estimates by the National Commission on Population (2006), the average age in India would be 31.39 years in 2026. This suggests that the young population is expected to play a crucial role in the future. Moreover, previous researchers suggested that educated young population has knowledge of updated technologies and they are expected to influence the elder members of the family in the adoption of new technologies (Seegeberth et al., 2016).

\section{Data Collection}

The data was generated from the students enrolled in various programmes in colleges affiliated to Dr. A.P.J. Abdul Kalam Technical University (AKTU), Uttar Pradesh (UP) and located in Aligarh district. AKTU is affiliating in nature and its jurisdiction spans the entire state of UP in affiliating various courses such as B.Tech, MBA, MCA, PhD., etc. AKTU follows strict norms to maintain the quality of education in its affiliated institutions. Hence, the students enrolled in AKTU affiliated colleges are expected to possess a threshold level of understanding in providing feedback to questionnaire employed in the present study.

A total of 500 questionnaires were distributed. Of these, only 277 responses were received, out of which, 135 were partially filled and hence, considered as unfit for further analysis. Thus, the analysis was performed on the feedback of 142 respondents. This sample size is line with the criterion of subject to the variable ratio of 5:1 suggested by a significant number of previous researchers for employing the Exploratory Factor Analysis (EFA) and Confirmatory Factor Analysis (CFA) (Hair et al., 2010; Malhotra \& Dash, 2011).

\section{Confirmatory Factor Analysis (CFA)}

To describe the cross loadings of items and correlation among the variables, CFA was employed on the variables obtained after EFA (Ahire et al., 1996; Khan \& Adil 2013; Ahmad \& Khan, 2017). The factor loadings for a majority of items were reasonably high (Figure 1 and Table 3 ) and hence, these items were retained onto their intended factor (Ryu et al., 2010). The values in Table 4 suggest that the model fit indices were within the acceptable range (Gerbing \& Anderson, 1988; Hu \& Bentler, 1999; Hair et al., 2010). 
Table 3: Standardized Regression Weights

\begin{tabular}{|c|c|c|c|}
\hline \multicolumn{3}{|r|}{ Path } & \multirow{2}{*}{$\begin{array}{c}\text { Estimate } \\
0.65\end{array}$} \\
\hline $\mathrm{S} 1$ & $\leftarrow$ & PR & \\
\hline $\mathrm{S} 2$ & $\leftarrow$ & PR & 0.94 \\
\hline S3 & $\leftarrow$ & PR & 0.80 \\
\hline S5 & $\leftarrow$ & $\mathrm{PC}$ & 0.58 \\
\hline S6 & $\leftarrow$ & $\mathrm{PC}$ & 0.95 \\
\hline S7 & $\leftarrow$ & $\mathrm{PC}$ & 0.71 \\
\hline S9 & $\leftarrow$ & Utility & 0.46 \\
\hline S10 & $\leftarrow$ & Utility & 0.67 \\
\hline S11 & $\leftarrow$ & Utility & 0.71 \\
\hline S13 & $\leftarrow$ & Utility & 0.66 \\
\hline S14 & $\leftarrow$ & Utility & 0.67 \\
\hline S15 & $\leftarrow$ & Utility & 0.72 \\
\hline S18 & $\leftarrow$ & PEU & 0.73 \\
\hline S19 & $\leftarrow$ & PEU & 0.83 \\
\hline S20 & $\leftarrow$ & PEU & 0.73 \\
\hline S22 & $\leftarrow$ & Intention & 0.76 \\
\hline $\mathrm{S} 23$ & $\leftarrow$ & Intention & 0.89 \\
\hline S25 & $\leftarrow$ & Intention & 0.54 \\
\hline S27 & $\leftarrow$ & IIT & 0.67 \\
\hline S29 & $\leftarrow$ & IIT & 0.88 \\
\hline S30 & $\leftarrow$ & IIT & 0.80 \\
\hline
\end{tabular}

Table 4: Fit Indices of Measurement Model (CFA)

\begin{tabular}{ccc}
\hline Fit Index & $\begin{array}{c}\text { Recommended } \\
\text { Values* }\end{array}$ & $\begin{array}{c}\text { Observed } \\
\text { Values }\end{array}$ \\
\hline CMIN/DX & $<0.30$ & 1.581 \\
GFI & 0.90 & 0.846 \\
AGFI & 0.80 & 0.795 \\
CFI & 0.90 & 0.926 \\
RMSEA & $<0.70$ & 0.064 \\
\hline
\end{tabular}

Notes: *Hu and Bentler (1998); Hair et al. (2010); Malhotra and Dash (2011) 
Figure 1: Measurement Model

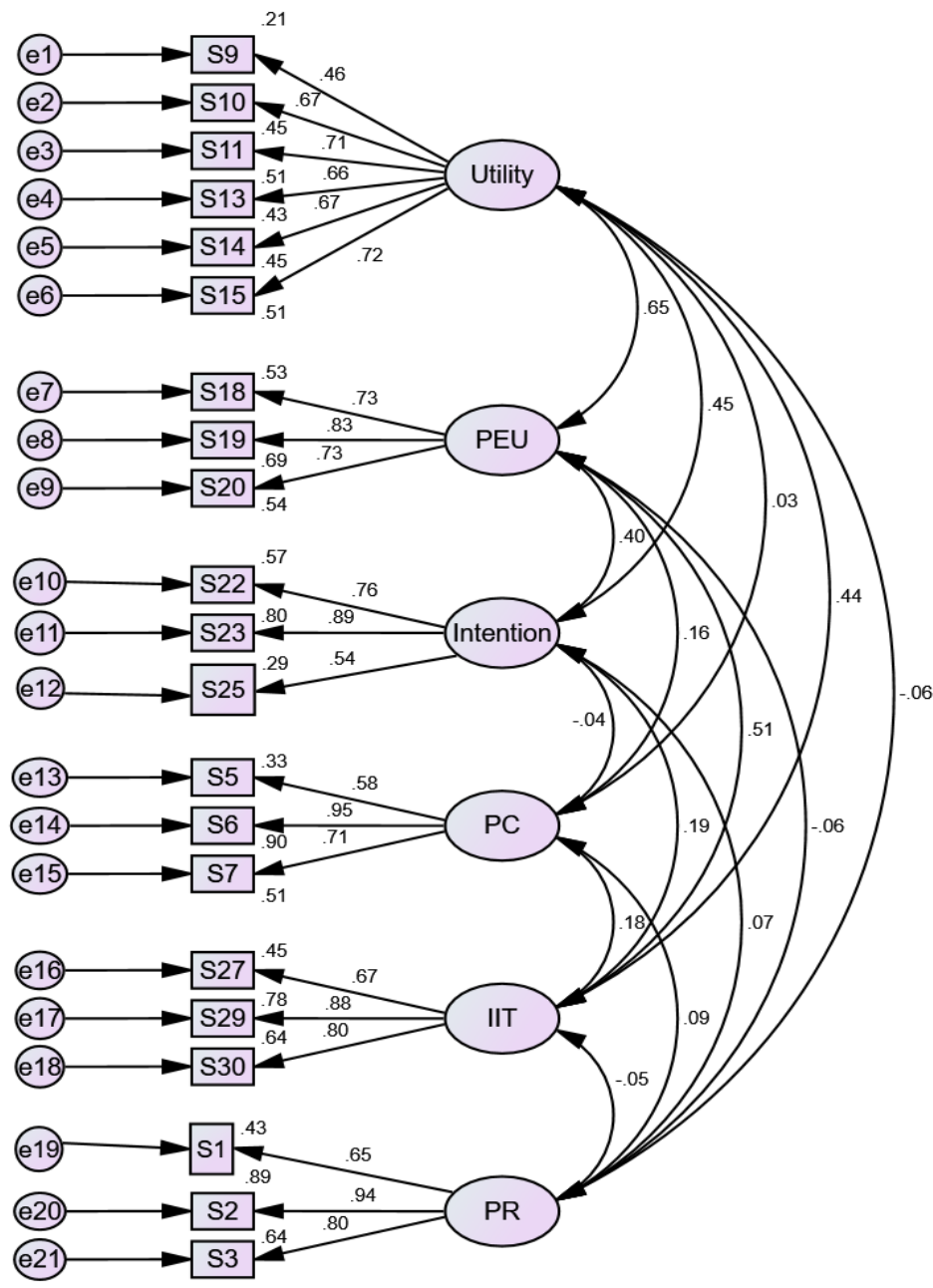

\section{Scale Validation}

In Table 5, the values of Average variance extracted (AVE) for all variables were above 0.5, indicating adequate convergent validity (Fornell \& Larcker, 1981; O’Leary- Kelly \& Vokurka, 1998; Hair et al. 2010; Khan \& Adil, 2013). Further, the square root of AVE (diagonal values highlighted in Table 5) is greater than the 'interconstruct' correlation, confirming acceptable discriminant validity (Fornell \& Larcker, 1981; O’Leary-Kelly \&Vokurka 1998; Hair et al. 2010; Khan \& Adil, 2013). The values for CR were also within the acceptable range $(>0.7)$ indicating adequate 
composite reliability (Fornell \& Larcker, 1981; Hair et al., 2010; Malhotra \& Dash, 2011).

Table 5: Reliability and Validity

\begin{tabular}{lcccccccc}
\hline & CR & AVE & IIT & Utility & PEU & Intention & PC & PR \\
\hline IIT & 0.850 & 0.657 & $\mathbf{0 . 8 1 1}$ & & & & & \\
Utility & 0.861 & 0.509 & 0.402 & $\mathbf{0 . 7 1 3}$ & & & & \\
PEU & 0.793 & 0.562 & 0.483 & 0.520 & $\mathbf{0 . 7 4 9}$ & & & \\
Intention & 0.799 & 0.585 & 0.076 & 0.425 & 0.386 & $\mathbf{0 . 7 6 5}$ & & \\
PC & 0.829 & 0.622 & 0.202 & 0.014 & 0.182 & -0.058 & $\mathbf{0 . 7 8 8}$ & \\
PR & 0.867 & 0.692 & -0.125 & -0.152 & -0.121 & 0.073 & -0.010 & $\mathbf{0 . 8 3 2}$ \\
\hline
\end{tabular}

Notes: IIT = Innovativeness in Information Technology; PEU = Perceived Ease of Use; $\mathrm{PC}=$ Perceived Cost; PR = Perceived Risk

\section{Second Order Measurement Model}

The next step for further generalisability, a second-order measurement model has been suggested by the previous researchers to assess the relationship between the main construct and the underlying constructs (Hinkin, 1995; Bowen \& Guo, 2011). In the present study, the theory suggests that the construct Mobile Commerce Acceptance (MCA) consists of six underlying sub-constructs each measured by some observed variables. As per the suggestions of Marsh and Hocevar (1985) a second order measurement model was developed and validated.

The results indicated that the model has a good model fit with values as follows: $\mathrm{CMIN} / \mathrm{df}=2.069 ; \mathrm{CFI}=0.920 ; \mathrm{GFI}=0.894 ; \mathrm{AGFI}=0.852 ; \mathrm{RMSEA}=0.074$. Out of the six sub-constructs, only four (utility, perceived ease of use, intention and innovation in information technology) loaded significantly on the main construct (Table 6 and Figure 2). The other two constructs i.e. perceived risk (PR) and perceived cost (PC) do not load significantly on MCA. Thus, MCA is established as a second order construct that is determined by the four constructs.

Table 6: Regression Path Coefficients and their Significance

\begin{tabular}{lcccccc}
\hline \multicolumn{2}{c}{ Path } & Estimate & S.E. & C.R. & $\boldsymbol{p}$ & Results \\
\hline Utility & $\leftarrow$ MCA & 0.801 & 0.262 & 4.193 & 0.000 & Significant \\
PEU & $\leftarrow$ MCA & 0.836 & 0.310 & 4.978 & 0.000 & Significant \\
Intention & $\leftarrow$ MCA & 0.507 & 0.254 & 4.158 & 0.000 & Significant \\
IIT & $\leftarrow$ MCA & 1 & \multicolumn{4}{c}{ Reference Point } \\
\hline
\end{tabular}


Figure 2: Second Order Measurement Model

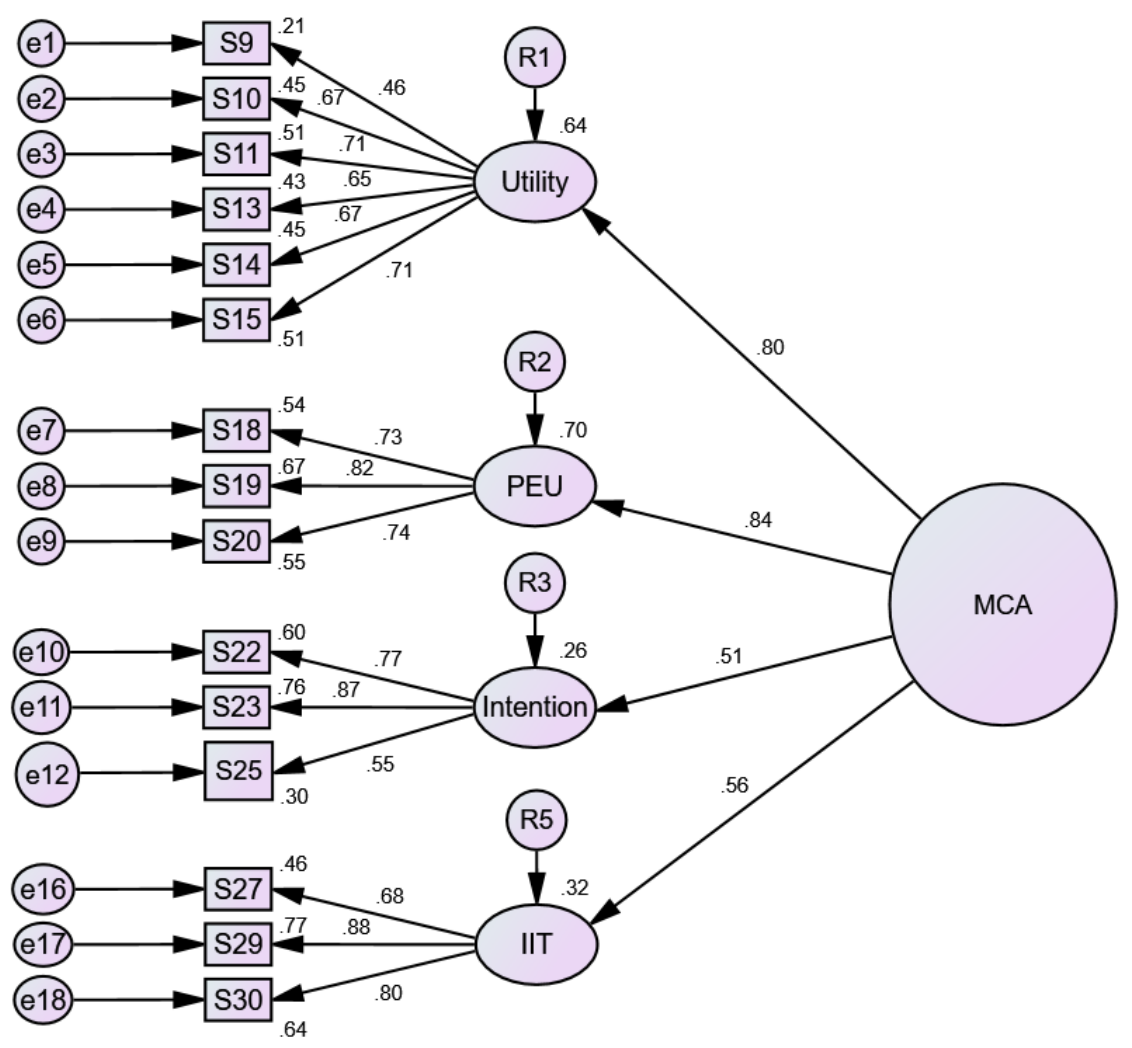

The summary of the final structure obtained after second order CFA can be observed in Table 7.

Table 7: Final Mobile Commerce Acceptance Scale (MC scale) for Indian Consumers

\begin{tabular}{llc}
\hline Variables & Items & $\begin{array}{c}\text { No. of } \\
\text { Items }\end{array}$ \\
\hline Utility & S9, S10, S11, S13, S14 and S15 & 06 \\
Perceived Ease of Use (PEU) & S18, S19 and S20 & 03 \\
Intention to Use (Intention) & S22, S23 and S25 & 03 \\
Innovations in Information & S27, S29 and S30 & 03 \\
Technology (IIT) & \\
Mobile Commerce Acceptance Scale for Indian Consumers & 15 \\
(MC scale) & \\
\hline
\end{tabular}




\section{Discussion}

Findings of the study highlighted that positive factors such as utility, perceived ease of use, intention and innovation in information technology ARE important for educated young Indian consumers residing in the non-metropolitan part of the country. This supports earlier studies such as Wu and Wang (2005) and June (2014) which also opined that positive factors are crucial for mobile commerce acceptance. However, while their findings were limited to the metropolitan global consumers, this study confirms the applicability of these factors to the non-metropolitan townships in India. Study findings also support studies such as Davis (1989), Venkatesh and Davis (2000), Venkatesh and Bala (2008) in the context of technological acceptance in general, that the consumer acceptance of a new technology can be explained with the help of positive factors such as perceived ease of use, utility, intention and innovation. However, findings of the present study contradicts the presumptions of some earlier researchers, that for non-metropolitan Indian consumers, cost (Kumar, 2007; Maheshkar et al., 2018) and risk (Chauhan, 2015) are the important considerations. This suggests that educated young consumers in non-metopolitan Indian small towns resemble their global counterparts in relying more on positive factors than negative factors such as cost and risk. On a broader note, it can be proposed that nonmetropolitan consumers are ambitious and choose innovativeness over cost and risk for using a new technology.

All the four constructs of MC Scale are discussed below:

Utility. The 6-item scale construct of Utility measures the consumer compatibility and their perceived usefulness related to the usage of m-commerce. Both compatibility and perceived usefulness are considered as key predecessors of consumer decision to embrace new technology (Agarwal \& Prasad, 1998; Kim et al., 2009; Lewis et al., 2003; Lu et al., 2005; Taylor \& Strutton, 2010). In this regard, the construct Utility is expected to be a significant contributor in the MC scale. The high score of the construct Utility will be an indication that users are ready to embrace mobile commerce. This would be an indicator to marketers that they must focus on designing well-targeted strategies to stimulate consumers for eventual acceptance.

Perceived ease of use (PEU). PEU measures the perception of consumers that the use of mobile technology involves minimum of mental efforts. The 3-item scale for PEU is expected to be crucial for the post-adoption usage of the mobile technology (Taylor \& Strutton, 2010; Choi et al., 2011). This scale will help marketers to determine the need for educating consumers and providing them training related to the use of the 
mobile phone technology. Especially, this construct would be particularly useful for determining the m-commerce acceptance behaviour of Indian rural consumers who constitute the majority of the Indian population (Ministry of Home Affairs, 2011; Lu et al., 2016), albeit being mindful of the segment of this population studied in this research.

Perceived innovation in information technology (IIT). The 3-item scale of PIIT is the determinant of consumer disposition to use and experiment with new technologies. The rapid diffusion of mobile phone technology in small towns and villages in India necessitates the understanding of the readiness of Indian consumers to embrace mobile phone technology for the purpose of online transactions (Bali, 2016; Kalaari Capital Report, 2018). In this regard, the construct PIIT would help marketers to design their promotional campaigns based on the readiness of consumers to engage with a new technology.

Intention to use (Intention). The construct intention measures the readiness of consumers to embrace m-commerce for various types of transactions. This 3 -item construct is also expected to reflect the degree of consumer forbearance for the risk and cost associated with $\mathrm{m}$-commerce and the degree of consumer acceptance that $\mathrm{m}$ commerce offers utility to them.

Thus, the MC scale proposed in this paper, comprising factors such as utility, perceived ease of use, perceived innovation in information technology and intention to use can be crucial for an improved understanding of educated young Indian consumers residing in non-metropolitan small towns.

\section{Conclusion}

The MC scale proposed in the present study would greatly help academicians and researchers for a deeper understanding of factors influencing mobile commerce acceptance by Indian consumers of non-metropolitan cities. An important contribution of the present study is that it validates that young non-metropolitan consumers in India are on the same line as the consumers in metropolitan cities across the globe. Similar to global consumers, non-metropolitan Indian consumers give more preference to the factors such as utility, perceived ease of use and innovativeness over the factors such as cost and risk.

In this regard, the proposed scale would also assist marketers in developing appropriate strategies. The marketers must prioritise interests and concerns of Indian 
consumers by focusing on the four factor scale. The present study was based on the premise that the understanding of factors important for $\mathrm{m}$-commerce acceptance by non-metropolitan Indian consumers is crucial for deciding future strategies for $\mathrm{m}$ commerce promotion in India. In this regard, the well-defined MC scale for Indian consumers residing in non-metropolitan cities is an important contribution of the present study.

However, the findings of this study are limited to the consumers residing in small towns. A significant proportion of non-metropolitan Indian population also reside in villages and it has been reported in earlier studies that the Indian rural consumers possess a very distinct set of characteristics (Ministry of Home Affairs, 2011; Lu et al., 2016). Thus, researchers must undertake fresh studies in future to validate the significance of the MC scale for rural consumers. Further, the scale can also be revalidated for consumers of different demographic groups, primarily for consumers of different age groups and different level of educational qualifications since this stuy utilzed students from one university to represent all young educated people in nonmetropoliton areas. Future researchers should also revalidate the present scale based on consumer feedback covering a wider geographical area. Present study has only developed a scale focusing on the constructs crucial for acceptance of m-commerce. There is scope for future researchers to propose a contextualised complete technological acceptance model for mobile commerce in the context of nonmetropolitan Indian consumers using scale developed in the present study.

\section{Declaration of Conflict of Interest}

The authors declared no potential conflict of interest with respect to the research, authorship, and publication of this article.

\section{References}

Agarwal, R., \& Prasad, J. (1998). A conceptual and operational definition of personal innovativeness in the domain of information technology. Information Systems Research, 9(2), 204-215. https://doi.org/10.1287/isre.9.2.204

Ahire, S. L., Golhar, D. Y., \& Waller, M. A. (1996). Development and validation of TQM implementation constructs. Decision Sciences, 27(1), 23-56. https://doi.org/10.1111/j.1540-5915.1996.tb00842.x

Ahmad, A., \& Khan, M. N. (2017). Developing a website service quality scale: A confirmatory factor analytic approach. Journal of Internet Commerce, 16(1), 104-126. https://doi.org/10.1080/15332861.2017.1283927

Akter, S., D'Ambra, J., \& Ray, P. (2011). Trustworthiness in mHealth information services: An assessment of a hierarchical model with mediating and moderating 
effects using partial least squares (PLS). Journal of the American Society for Information Science and Technology, 62(1), 100-116. https://doi.org/10.1002/asi.21442

Aldas-Manzano, J., Ruiz-Mafé, C., \& Sanz-Blas, S. (2009). Exploring individual personality factors as drivers of M-shopping acceptance. Industrial Management $\begin{array}{llll}\text { and Data } & \text { Systems, } & \text { 109(6), } & \text { 7397. }\end{array}$ https://doi.org/10.1108/02635570910968018

Associated Chambers of Commerce and Industry in India (2017). Digital commerce market expected to cross $\$ 50$ bn mark in 2018: Study. https://www.assocham.org/newsdetail.php?id=6654

Ba, S., \& Pavlou, P. A. (2002). Evidence of the effect of trust building technology in electronic markets: Price premiums and buyer behavior. MIS Quarterly, 26(3), 243-268. https://www.jstor.org/stable/4132332?origin=crossref\&seq=1\#meta data info tab contents

Bagozzi, R. P., \& Yi, Y. (1988). On the evaluation of structural equation models. Journal of the Academy of Marketing Science, 16(1), 74-94.

Bali, (2016, March 22). A smart footprint. The Financial Express. https://www.financialexpress.com/industry/technology/a-smart-footprint/22841 8/

Bowen, N. K., \& Guo, S. (2011). Structural equation modeling. Oxford University Press.Central Statistics Office. (2017). Youth in India. New Delhi:. http://mospi.nic.in/sites/default/files/publication_reports/Youth_in_India-2017. pdf

Chauhan, S. (2015). Acceptance of mobile money by poor citizens of India: Integrating trust into the technology acceptance model. Info. 17(3), 58--68. https://doi.org/10.1108/info-02-2015-0018

Cheng, T. E., Lam, D. Y., \& Yeung, A. C. (2006). Adoption of internet banking: An empirical study in Hong Kong. Decision Support Systems, 42(3), 1558-1572. https://doi.org/10.1016/j.dss.2006.01.002

Cho, J. (2004). Likelihood to abort an online transaction: influences from cognitive evaluations, attitudes, and behavioral variables. Information \& Management, 41(7), 827-838. https:// doi.org/10.1016/j.im.2003.08.013

Choi, H., Kim, Y., \& Kim, J. (2011). Driving factors of post adoption behavior in mobile data services. Journal of Business Research, 64(11), 1212-1217. https:// doi.org/10.1016/j.jbusres.2011.06.025

Choi, S. (2018). What promotes smartphone-based mobile commerce? Mobilespecific and self-service characteristics. Internet Research. 28(1), 105-102.

Chong, A. Y.-L., Chan, F. T. S., \& Ooi, K.-B. (2012). Predicting consumer decisions to adopt mobile commerce: cross country empirical examination between China 
and Malaysia. Decision Support Systems, 53(1), 34-43. https://doi.org/ 10.1016/j.dss.2011.12.001

Chong, A. Y.-L., Darmawan, N., Ooi, K.-B., \& Lin, B. (2010). Adoption of 3G services among Malaysian consumers: An empirical analysis. International Journal of Mobile Communications. 8, 129-149. https://doi.org/10.1504/ IJMC.2010.031444

Chong, A. Y.-L., Ooi, K.-B., Lin, B., \& Tan, B.-I. (2010). Online banking adoption: An empirical analysis. International Journal of Bank Marketing. 28(4), 267-287. https://doi.org/10.1108/02652321011054963

Chou, S.-W., Min, H.-T., Chang, Y.-C., \& Lin, C.-T. (2010). Understanding continuance intention of knowledge creation using extended expectationconfirmation theory: An empirical study of Taiwan and China online communities. Behaviour and Information Technology. 29(6), 557-570. https://doi.org/10.1080/01449290903401986

Churchill, G. A., Jr. (1979). A paradigm for developing better measures of marketing constructs. Journal of Marketing Research, 16(1), 64-73. https://www.jstor. org/stable/3150876?seq=1

Clarke, I., III. (2008). Emerging value propositions for m-commerce. Journal of Business Strategies, 25(2), 41-57.

Cooper, D. R., \& Schindler, P. S. (2013). Business research methods (12 ${ }^{\text {th }}$ Ed.), McGraw-Hill Education.

Dai, H., \& Palvia, P. (2008). Factors affecting mobile commerce adoption: A crosscultural study in China and the United States. The DATA BASE for Advances in Information Systems, 40, 43-61.

Davis, F. D. (1989). Perceived usefulness, perceived ease of use, and user acceptance of information technology. MIS Quarterly, 13(3), 319-340. https://www.jstor. org/stable/249008?seq=1

Eastin, M. S. (2002). Diffusion of e-commerce: An analysis of the adoption of four E-commerce activities. Telematics and Informatics, 19(3), 251-267. https://doi.org/10.1016/S0736-5853(01)00005-3

Feng, H., Hoegler, T., \& Stucky, W. (2007). Exploring the critical success factors for mobile commerce. Proceedings of the International Conference on Mobile Business, 40-48. https://ieeexplore.ieee.org/document/4124135

Fishbein, M. A., \& Ajzen, I. (1975). Belief, attitude, intention and behavior: An introduction to theory and research. Addison-Wesley.

Fornell, C., \& Larcker, D. F. (1981). Evaluating structural equation models with unobservable variables and measurement error. Journal of Marketing Research, 18(1), 39-50. https://www.jstor.org/stable/3151312?seq=1 
Forsythe, S. M., \& Shi, B. (2003). Consumer patronage and risk perceptions in internet shopping. Journal of Business Research, 56(11), 867-875. https://doi.org/10.1016/S0148-2963(01)00273-9

Gefen, D., \& Straub, D. (2003). Managing user trust in B2C e-services. $e$-Service Journal, 2(2), 7-24. https://www.jstor.org/stable/10.2979/esj.2003.2.2.7?seq=1

Gerbing, D. W., \& Anderson, J. C. (1988). An updated paradigm for scale development incorporating unidimensionality and its assessment. Journal of Marketing Research, 25(2), 186-192. https://www.jstor.org/stable/3172650? seq $=1$

Grandon, E. E., \& Pearson, J. M. (2004). Electronic commerce adoption: an empirical study of small and medium US businesses. Information \& Management, 42(1), 197-216.

GSM Association (2020). The mobile economy - 2020. https://www.gsma.com/ mobileeconomy/wpcontent/uploads/2020/03/GSMA MobileEconomy2020 G1 obal.pdf

Ha, I., Yoon, Y., \& Choi, M. (2007). Determinants of adoption of mobile games under mobile broadband wireless access environment. Information \& Management, 44(3), 276-286. https://doi.org/10.1016/j.im.2007.01.001

Hair, J. F., Black, W. C., Babin, B. J., Anderson, R. E., \& Tatham, R. L. (1998). Multivariate data analysis ( $\left.5^{\text {th }} \mathrm{ed},\right)$. Prentice hall.

Hair, J.F., Black, W.C., Babin, B.J., and Anderson, R.E. (2010). Multivariate data analysis $\left(7^{\text {th }}\right.$ Ed). Pearson Prentice Hall.

Han, S., Mustonen, P., Seppanen, M., \& Kallio, M. (2006). Physicians' acceptance of mobile communication technology: An exploratory study. International Journal of Mobile Communications, 4(2), 210-230. https://doi.org.10.1504/IJMC.2006. $\underline{008610}$

Hinkin, T. R. (1995). A review of scale development practices in the study of organizations. Journal of Management, 21(5), 967-988. https://doi.org/10.1177/ $\underline{014920639502100509}$

Hsu, C.-L., \& Lu, H.-P. (2004). Why do people play on-line games? An extended TAM with social influences and flow experience. Information \& management, 41(7), 853-868. https://doi.org/10.1016/j.im.2003.08.014

Hu, L.-T., \& Bentler, P. M. (1999). Cutoff criteria for fit indexes in covariance structure analysis: Conventional criteria versus new alternatives. Structural Equation Modeling: A Multidisciplinary Journal, 6(1), 1-55. https://doi.org/10. $\underline{1080 / 10705519909540118}$

Hung, M.-C., Hwang, H.-G., \& Hsieh, T.-C. (2007). An exploratory study on the continuance of mobile commerce: An extended expectation-confirmation model 
of information system use. International Journal of Mobile Communications, 5(4), 409-422. https://dx.doi.org/10.1504/IJMC.2007.012788 Hung, M.-C., Yang, S.-T., \& Hsieh, T.-C. (2012). An examination of the determinants of mobile shopping continuance. International Journal of Electronic Business Management, 10(1), 29-37.

Jeyaraj, A., Rottman, J. W., \& Lacity, M. C. (2006). A review of the predictors, linkages, and biases in IT innovation adoption research. Journal of Information Technology, 21(1), 1-23. https://doi.org/10.1057/palgrave.jit.2000056

June, L. (2014). Are personal innovativeness and social influence critical to continue with mobile commerce. Internet Research, 24(2), 134-159. https://doi.org/ $\underline{10.1108 / \text { IntR-05-2012-0100 }}$

Kalaari Capital Report. (2018). Imagining trillion dollar digital India. https://kstart.in/wp-content/uploads/2018/04/Imagining-Trillion-Dollar-DigitalIndia-IBM-Kalaari-Research-Report-April-2018.pdf

Kerlinger, F. N., \& Lee. H. B. (2000). Foundations of behavioral research $\left(4^{\text {th }} d\right.$.). Wadsworth.

Khan, M. N., \& Adil, M. (2013). Data analysis techniques in service quality literature: Essentials and advances. Serbian Journal of Management, 8(1), 95-112. https:// cyberleninka.org/article/n/477877/viewer

Kim, B. (2012). The diffusion of mobile data services and applications: Exploring the role of habit and its antecedents. Telecommunications Policy, 36(1), 69-81. https://doi.org/10.1016/j.telpol.2011.11.011

Kim, D. J., Ferrin, D. L., \& Rao, H. R. (2009). Trust and satisfaction, two stepping stones for successful e-commerce relationships: A longitudinal exploration. Information Systems Research, 20(2), 237-257. https://pubsonline.informs.org/ doi/10.1287/isre.1080.0188

Kline, P. (1994). An easy guide to factor analysis. London: Routledge.

Kumar, L. R. (2007). Role of marketing communication in enhancement of quality of life in rural India. Intercultural Communication Studies, 16(1), 46-55.

Kwon, O., Choi, K., \& Kim, M. (2007). User acceptance of context-aware services: self-efficacy, user innovativeness and perceived sensitivity on contextual pressure. Behaviour \& Information Technology, 26(6), 483-498. https://doi.org/ $\underline{10.1080 / 01449290600709111}$

Lederer, A. L., Maupin, D. J., Sena, M. P., \& Zhuang, Y. (2000). The technology acceptance model and the World Wide Web. Decision Support Systems, 29(3), 269-282. https://doi.org/10.1016/S0167-9236(00)00076-2

Lewis, W., Agarwal, R., \& Sambamurthy, V. (2003). Sources of influence on beliefs about information technology use: An empirical study of knowledge 
workers. MIS Quarterly 27(4), 657-678. https://www.jstor.org/stable/30036552? seq=1\#metadata_info_tab_contents

Liébana-Cabanillas, F., Marinković, V., \& Kalinić, Z. (2017). A SEM-neural network approach for predicting antecedents of $\mathrm{m}$-commerce acceptance. International Journal of Information Management, 37(2), 14-24. https://doi.org/10.1016/ j.ijinfomgt.2016.10.008

Lin, T. C., \& Chen, C. J. (2012). Validating the satisfaction and continuance intention of e-learning systems: Combining TAM and IS success models. International Journal of Distance Education Technologies (IJDET), 10(1), 44-54. https: //www.learntechlib.org/p/167550/

Lin, Y.-M., \& Shih, D.-H. (2008). Deconstructing mobile commerce service with continuance intention. International Journal of Mobile Communications, 6(1), 67-87. https://doi.org/10.1504/IJMC.2008.016000

Liu, C., \& Forsythe, S. (2011). Examining drivers of online purchase intensity: Moderating role of adoption duration in sustaining post-adoption online shopping. Journal of Retailing and Consumer Services, 18(1), 101-109. https://doi.org/10.1016/j.jretconser.2010.10.004

Lu, J., Yao, J. E., \& Yu, C.-S. (2005). Personal innovativeness, social influences and adoption of wireless Internet services via mobile technology. The Journal of Strategic Information Systems, 14(3), 245-268. https://doi.org/10.1016/ j.jsis.2005.07.003

Lu, J., Yiu, A. \& Soman, A. (2016). The Asian consumer-Indian consumer close up: tapping the spending power of a young, connected urban mass. Goldman Sachs Report. http://www.goldmansachs.com/our-thinking/pages/macroeconomicinsights-folder/rise-of-the-india-consumer/report.pdf .

Lu, J., Yu, C.-S., Liu, C., \& Yao, J. E. (2003). Technology acceptance model for wireless internet. Internet Research, 13(2), 206-222. https://doi.org/ $\underline{10.1108 / 10662240310478222}$

Lucas, H. C., Jr., \& Spitler, V. (2000). Implementation in a world of workstations and networks. Information \& Management, 38(2), 119-128. https://doi.org/ $\underline{10.1016 / \mathrm{S} 0378-7206(00) 00059-8}$

Maheshkar, C., Sharma, V., Kapse, M., \& Tiwari, A. (2018). Impact of advertising on branding in small towns and villages of India. Ushus-Journal of Business Management, 17(4), 15-40. https://doi.org/10.12725/ujbm.45.2

Malhotra, N. K. (2008). Marketing research: An applied orientation ( $5^{\text {th }}$ Ed.). Pearson Education.

Malhotra, N. K., \& Dash, S. 2011. Marketing research: An applied orientation (6 $6^{\text {th }}$ ed.). Pearson Education. 
Marsh, H. W. and Hocevar, D. (1985). Application of confirmatory factor analysis to the study of self-concept: First-and higher order factor models and their invariance across groups. Psychological Bulletin, 97(3), 562-582. https://doi.org/10.1037/0033-2909.97.3.562

McKinsey Global Institute. (2014). India's technology opportunity: Transforming work, empowering people. https://www.mckinsey.com/ /media/mckinsey/ industries/high\%20tech/our\%20insights/indias\%20tech\%20opportunity\%20tran sforming\%20work\%20empowering\%20people/mgi\%20india\%20tech_full\%20r eport december\%202014.ashx.

Metin, M., Yilmaz, G. K., Coskun, K., \& Birisci, S. (2012). Developing an attitude scale towards using instructional technologies for pre-service teachers. Turkish Online Journal of Educational Technology-TOJET, 11(1), 36-45. https://eric.ed. gov/?id=EJ976568

Ministry of Home Affairs (2011). Census of India. Government of India.

Mohsin, M., Muqtadir, R., \& Ishaq, A. (2003). Mobile commerce-The emerging frontier: Exploring the prospects, applications and barriers to adoption in Pakistan. Paper presented at the International Workshop on Frontiers of IT, Islamabad.

Moorman, C., Zaltman, G., \& Deshpande, R. (1992). Relationships between providers and users of market research: The dynamics of trust within and between organizations. Journal of Marketing Research, 29(3), 314-328. https://www.jstor.org/stable/3172742?seq=1\#metadata_info_tab_contents

National Commission on Population. (2006). Population projections for India and states 2001-2026. https://www.educationforallinindia.com/Population Projection Report_2006.pdf

Ng, E. H., \& Kwahk, K. Y. (2010). Examining the determinants of mobile internet service continuance: A customer relationship development perspective. International Journal of Mobile Communications, 8(2), 210-229. https://doi.org/10.1177/0266666914522140

Nysveen, H., Pedersen, P. E., \& Thorbjørnsen, H. (2005). Intentions to use mobile services: Antecedents and cross-service comparisons. Journal of the Academy of Marketing Science, 33(3), 330-346. https://doi.org/10.1177/0092070305276149

O'Leary-Kelly, S. W., \& J. Vokurka, R. (1998). The empirical assessment of construct validity. Journal of Operations Management, 16(4), 387-405. https://doi.org/ 10.1016/S0272-6963(98)00020-5

Plouffe, C. R., Hulland, J. S., \& Vandenbsch, M. (2001). Richness versus parsimony in modeling technology adoption decisions-Understanding merchant adoption of a smart card-based payment system. Information Systems Research, 12(2), 208-222. https://doi.org/10.1287/isre.12.2.208.9697 
Press Trust of India (2017, December 26). E-commerce market may cross $\$ 50$ bn mark in 2018: Study. The Economic Times. https://retail.economictimes. indiatimes.com/news/e-commerce/e-tailing/e-commerce-market-may-cross-50bn-mark-in-2018-study/62246619

Rondan-Cataluña, F. J., Arenas-Gaitán, J., \& Ramírez-Correa, P. E. (2015). A comparison of the different versions of popular technology acceptance models: A non-linear perspective. Kybernetes, 44(5), 788-805. https://doi.org/10.1108/K09-2014-0184

Ryu, K., Han, H., \& Jang, S. (2010). Relationships among hedonic and utilitarian values, satisfaction and behavioral intentions in the fast-casual restaurant industry. International Journal of Contemporary Hospitality Management, 22(3), 416-432. https://doi.org/10.1108/09596111011035981

Sadia, S. (2011). User acceptance decision towards mobile commerce technology: a study of user decision about acceptance of mobile commerce technology. Interdisciplinary Journal of Contemporary Research in Business, 2(12), 535547.

Sekaran, U. (2003). Research methods for business: a skill-building approach $\left(4^{\text {th }}\right.$ ed). Wiley.

Statista.com (2016). Retail m-commerce sales in India from 2015 to 2020 (in billion US dollars). https://www.statista.com/statistics/266119/india-retail-mcomme rce-sales/.

Suh, B., \& Han, I. (2002). Effect of trust on customer acceptance of internet banking. Electronic Commerce Research and Applications, 1(3-4), 247-263. https://doi.org/10.1016/S1567-4223(02)00017-0

Sultan, F., \& Mooraj, H. A. (2001). Designing a trust-based e-business strategy. Marketing Management, 10(4), 40-45.

Sun, H. (2012). Understanding user revisions when using information system features: Adaptive system use and triggers. MIS Quarterly, 36(2), 453-478. https://www.jstor.org/stable/41703463?seq=1\#metadata_info_tab_contents

Szajna, B. (1996). Empirical evaluation of the revised technology acceptance model. Management Science, 42(1), 85-92. https://www.jstor.org/stable/2633017

Tanwar, K.. \& Prasad, A., (2017). Employer brand scale development and validation: A second-order factor approach. Personnel Review, 46(2), 389-409. https://doi.org/10.1108/PR-03-2015-0065

Taylor, D. G., \& Strutton, D. (2010). Has e-marketing come of age? Modeling historical influences on post-adoption era Internet consumer behaviors. Journal of Business Research, 63(9-10), 950-956. https://doi.org/10.1016/ j.jbusres.2009.01.018 
Taylor, J. W. (1974). The role of risk in consumer behavior: A comprehensive and operational theory of risk taking in consumer behavior. Journal of marketing, 38(2), 54-60. https://doi.org/10.1177/002224297403800211

Thakur, R., \& Srivastava, M., (2013). Customer usage intention of mobile commerce in India: An empirical study. Journal of Indian Business Research, 5(1), 52-72. https://doi.org/10.1108/17554191311303385

Tiwari, R., \& Buse, S. (2007). The mobile commerce prospects: A strategic analysis of opportunities in the banking sector. Hamburg University Press.

Trivedi, J.P., \& Kumar, S. (2014). Determinants of mobile commerce acceptance amongst gen Y. Journal of Marketing Management, 2(2), 145-163.

Varshney, U., \& Vetter R. (2002). Mobile commerce: framework, applications and networking support. Mobile Networks and Applications, 7, 185-198. https://doi.org/10.1023/A:1014570512129

Venkatesh, V., \& Bala, H. (2008). Technology acceptance model 3 and a research agenda on interventions. Decision Sciences, 39(2), 273-315. https://doi.org/10.1111/j.1540-5915.2008.00192.x

Venkatesh, V., \& Davis, F. D. (2000). A theoretical extension of the technology acceptance model: Four longitudinal field studies. Management Science, 46(2), 186-204. https://doi.org/10.1287/mnsc.46.2.186.11926

Venkatesh, V., \& Morris, M. G. (2000). Why don't men ever stop to ask for directions? Gender, social influence, and their role in technology acceptance and usage behavior. MIS Quarterly, 24(1), 115-139. https://doi.org/10.2307/3250981

Wallace, L. G., \& Sheetz, S. D. (2014). The adoption of software measures: A technology acceptance model (TAM) perspective. Information \& Management, 51(2), 249-259. https://doi.org/10.1016/j.im.2013.12.003

Warrington, T. B., Abgrab, N. J., \& Caldwell, H. M. (2000). Building trust to develop competitive advantage in e-business relationships. Competitiveness Review: An International Business Journal, 10(2), 160-168. https://doi.org/10.1108/ $\underline{\mathrm{eb} 046409}$

Wei, T. T., Marthandan, G., Chong, A. Y.-L., Ooi, K.-B., \& Arumugam, S. (2009). What drives Malaysian m-commerce adoption? An empirical analysis. Industrial Management \& Data Systems, 109(3), 370-388. https://doi.org/10.1108/ $\underline{02635570910939399}$

Wijesundara, T. R., \& Xixiang, S. (2018). Social networking sites acceptance: The role of personal innovativeness in information technology. International Journal of Business and Management, 13(8), 75-85. http://www.ccsenet.org/journal/ index.php/ijbm/article/view/68982 
Wong, Y. K., \& Hsu, C. J. (2008). A confidence-based framework for business to consumer (B2C) mobile commerce adoption. Personal and Ubiquitous Computing, 12(1), 77-84. https://doi.org/10.1007/s00779-006-0120-5

Wu, I.-L., Li, J.-Y., \& Fu, C.-Y. (2011). The adoption of mobile healthcare by hospital's professionals: An integrative perspective. Decision support systems, 51(3), 587-596. https://doi.org/10.1016/j.dss.2011.03.003

Wu, J.-H., \& Wang, S.-C. (2005). What drives mobile commerce?: An empirical evaluation of the revised technology acceptance model. Information \& Management, 42(5), 719-729. https://doi.org/10.1016/j.im.2004.07.001

Yadav, R., Sharma, S. K., \& Tarhini, A. (2016). A multi-analytical approach to understand and predict the mobile commerce adoption. Journal of Enterprise Information Management, 29(2), 222-237. https://doi.org/10.1108/JEIM-042015-0034

Yang, S. C., Chatterjee, S., \& Chan, C. C. (2004). Wireless communications: Myths and reality. Communications of the Association for Information Systems, 13(1), 682-696. https://doi.org/10.17705/1CAIS.01339

Yi, M. Y., Fiedler, K. D., \& Park, J. S. (2006). Understanding the role of individual innovativeness in the acceptance of IT-based innovations: Comparative analyses of models and measures. Decision Sciences, 37(3), 393-426. https://doi.org/ 10.1111/j.1540-5414.2006.00132.x

Zhao, L., Lu, Y., \& Gupta, S. (2012). Disclosure intention of location-related information in location-based social network services. International Journal of Electronic Commerce, 16(4), 53-90. https://doi.org/10.2753/JEC1086$\underline{4415160403}$

Zhou, T. (2011). An empirical examination of users' post-adoption behaviour of mobile services. Behaviour \& Information Technology, 30(2), 241-250. https://doi.org/10.1080/0144929X.2010.543702 